\title{
\$sciendo
}

Ethics \& Bioethics (in Central Europe), 2020, 10 (1-2), 10-19

DOI:10.2478/ebce-2020-0003

\section{Dying in dignity ${ }^{1}$}

\section{Marcus Knaup ${ }^{2}$}

\begin{abstract}
The question of what might constitute "good dying" is a sensitive subject that is being discussed and is socially and politically controversial. My contribution discusses whether a reference to concepts such as autonomy and dignity in the debate over suicide and euthanasia is in fact convincing. Important impulses for the train of thought stem from Kantian philosophy. I will argue that suicide, as presented by Kant, is not an expression of autonomy, but exactly the opposite: an expression of heteronomy.
\end{abstract}

Keywords: autonomy, dignity, euthanasia, Kant

\section{I.}

The question of what might constitute "good dying" is a sensitive subject that is being discussed and is socially and politically controversial. We encounter reference to the "dignity" of man, from which completely diverse consequences are drawn, and also reference to our "self-determination", especially in the last phase of our life (Hoffmann \& Knaup, 2015).

For example, it is being discussed whether suicide can also be dignified dying to escape hopelessness and a painful situation: "Today is the day I have chosen to pass away with dignity in the face of my incurable illness, this terrible brain tumour that has robbed me of so much [...] but which would have taken away so much more" (Todkranke Amerikanerin, 2014). This is from the Facebook page of 29-year-old Brittany Maynard who killed herself on November 1, 2014. She was in the final stage of cancer and had moved with her family from California to Oregon where medically assisted suicide is permitted under the Oregon Death with Dignity Act. There was also much sympathy in Germany with the fate of the young American. A controversial discussion came up about her personal decision and even more about the public announcement of her death.

In connection to this, it is also being debated whether others should be allowed to help people commit suicide who request it and are no longer capable of performing it by themselves. Norbert Hoerster, a German philosopher of jurisprudence, is not only concerned about "death on demand". He also wants to look at situations where people are no longer able to articulate their wish to die. If we could assume "with a degree of probability bordering on certainty" that the person in question is physically able to express the desire, then the act of assisted suicide would be admissible. (Hoerster, 2018)

According to Hoerster, we should be "very careful" with such an assumption. However, he feels that in principle there is nothing wrong with it, and he calls it "completely inhumane to deny such a person any assistance from the outset" (Hoerster, 1998, p. 70). It should also be mentioned that in September 2017, a Catholic order in Belgium reaffirmed its position to no longer categorically deny assisted suicide to patients in their own hospitals for patients in a non-terminal state of a

${ }^{1}$ The paper was presented at the international conference End of Life and Euthanasia - Intersection of Issues and Questions held in Prague (Czech Republic) on 4-5 November 2019.

${ }^{2}$ FernUniversität in Hagen, Faculty of Humanities and Social Sciences, Institute of Philosophy, Hagen (Germany); marcus.knaup@fernuni-hagen.de. 
physical illness (Sterbehilfe-Streit in Belgien, 2017). ${ }^{3}$ After all, they said, it would be a matter of dying in dignity. ${ }^{4}$ It becomes apparent here that the group of persons involved is being constantly enlarged: Already, people in the early stage of dementia and people "tired of living", seriously ill children and mental patients are counted as belonging to the group. In Belgium, children and youths can request assisted suicide while other important decisions and activities are left until the age of majority.

In the Netherlands in the meantime, dementia is now also regarded as an "unbearable suffering" and thus a sufficient prerequisite for assisted suicide. The road from killing on request to killing without request is not very long. "The more professionalized and standardized such 'acts of assistance' are performed, the closer they come to active killing which physicians commit by their own hand through injections" (Fuchs, 1997a, p. 87).

It is also being discussed how far human self-determination extends and whether suicide in the face of a bad diagnosis can be an expression of autonomy. In the debates, we find, again and again, statements according to which everyone has the "right" to die according to their convictions. They want to leave the stage of life with "self-determination". The time of one's death is to be in the realm of one's own discretion. We ought to be masters of our own time until the end. No illness is supposed to have the last word, and we should not lose control of that at any cost. Some philosophers also talk about the right of individuals to govern their own dignity and autonomy. This is also said to include the possibility to determine our own end. ${ }^{5}$

\footnotetext{
${ }^{3}$ During a conference in November 2017 of the Academy for Life, recently formed by Pope Francis, an advocate of euthanasia was invited as well. With regard to that, see the following critique by the John Paul II Academy For Human Life And The Family (2017).

${ }^{4}$ That violence against oneself per se is by no means legitimate was formulated as follows by Augustine: "Who kills himself also kills nothing but a human being" (Augustine, De civitate Dei I, 20). This seems to be no longer selfevident in theology. Characteristically, the fundamentalist theologian Magnus Striet of Freiburg, who constantly repeats that theology cannot go "back beyond Kant" and who chants the term "freedom" as if his mouth were a prayer mill, does not agree with Kant when it comes to suicide. "Here, we have to think beyond Kant" (Striet, 2015, pp. 99 ff.). He says that Kant was only a child of his time in that regard (Striet, 2015, p. 101). "Since God gave us the greatest gift possible, namely to be free, He also gave us an opportunity to freely determine whether we should end our life, to return it into the hands of Him who has bestowed it" (Striet, 2015, p.105). Striet ignores that suicide does away with freedom and that Kant mainly saw heteronomy at work. Probably Kant would have told this theologian: "A person committing suicide [...] antagonizes his creator's purpose; he arrives in the other world as one who has left his post; he is therefore to be regarded as a rebel against God. [...] We humans have been placed here as sentries and must not leave our post until another charitable hand can relieve us" (Kant, 1990, pp. 166 f.).

In several publications, the Swiss theologian Hans Küng has advocated that we should be able to take our own life. He thinks he can justify this with his belief in resurrection; since he believes in the continued existence after death, he can decide when and how to die. (Küng, 2014) However, he cannot invoke the New Testament's Easter Message. Küng, who dedicated all his life to his project of World Ethics, is now abandoning a fundamental conviction of the Abrahamic religions.

According to Thomas Aquinas, suicide is also contrary to the duty we owe to ourselves, to the community and to God. (Cf. Thomas Aquinas, Summa Theologiae II-II, Qu. 64). And Pope John Paul II, himself already old and feeble at the time, wrote in his Letter to the Elderly: "Surely it can happen that in cases of serious illness with unbearable suffering, the afflicted are tempted to give up completely. Then it can happen that their relatives or caretakers - out of misunderstood sympathy - feel motivated to regard 'gentle death' as a reasonable solution. In that connection we must remind you that moral law allows the abdication of so-called 'therapeutic zeal' and only demands the treatment required by means of normal medical care. But [...] directly causing death is another matter altogether! Regardless of the intentions and circumstances it remains a malfeasance per se, a violation of divine law, an insult to the dignity of human beings" (Brief von Johannes Paul II., 1999).

${ }^{5}$ For example, this is the position Ronald Dworkin, Thomas Nagel, Robert Nozick, John Rawls, Thomas Scanlon and Judith Jarvis Thomson take in their Philosopher's Letter (1997); (Sandel, 2015, pp. 170-174; Charlesworth, 1997). This point of view is also succinctly formulated by J. C. Wolf: "Those who want to live and can make some sense out
} 
In that sense, radio and television author Wolfgang Brosche compared the suicide of Udo Reiter with the behaviour of a Western hero and then advocated "autonomous dying" (Brosche, 2014). As an example, we can also refer to the American film romance "Me Before You", in which a caregiver and her paralyzed patient fall in love but that does not stop the patient from seeking assisted suicide in Switzerland. In October 2017, the German TV station ARD broadcast an evening on the subject of autonomous dying. Christiane Hörbiger, in the role of Katharina Krohn, suffering from arthrosis and chronic pneumonia, plans to end her life with the help of a Swiss euthanasia society - causing her two daughters to have very different reactions.

While assisted suicide is not criminal in Switzerland under section 115, Swiss Criminal Code (StGB), it is possible to accept the services of private societies who promise to provide "selfdetermined dying in dignity". ${ }^{6}$ In Austria, a cross-party Parliamentary Inquiry at the end of 2015 concluded that every form of assisted suicide remains prohibited. In Britain, assisted suicide was rejected in September 2015 by a clear majority. In Germany, in November 2015, a new section 217, StGB [German Criminal Code] was enacted that prohibits the "commercial" promotion of suicide. (Cf. Knaup, 2016)

There is no such thing as the right to commit suicide. ${ }^{7}$ It is an act that eludes the legal sphere. (cf. Spaemann, 2002, p. 432) The end does not just "belong to me" since I am not simply an object or my property. Persons committing suicide destroy themselves as moral persons; they see and treat themselves as objects by disposing of their life as if it were their property. However, we are not allowed to treat ourselves or others as a mere means. We cannot have the right to our own death or to assist in an act of killing. The dignity of man is manifested in that others must be recognized as legal persons. The existence of a "legal peer" must not be put at one's disposal; the state must protect the life of all "legal peers":

\begin{abstract}
"The idea of the law as a code for the coexistence of free people [...] directly excludes the authority of private persons to violate the conditions of coexistence or even to cause each other to die. The law itself can only refrain from the prohibition to kill when (as in the right of self-defence) it is a matter of maintaining the state of law against open injustice [...]. A society that kills without a legal reason or allows killing is therefore engaged in burying the idea of law itself and the rule of law" (Hoffmann, 2015, p. 9).
\end{abstract}

It is therefore particularly regrettable that in the Netherlands there is no protection for the conscience of nursing staff. The result is that they can be obligated to kill. In Belgium, there was a broad discussion about the question whether hospitals owned by religious institutions can be held accountable in terms of offering assisted suicide (Cf. Hoffmann, 2009, p. 69).

of their own life must not be eliminated by others who have a different evaluation of life. Thus, the internal evaluation of life must be recognized with authority. This blocks every attempt of legitimizing a centralized political decision about life or death as in the racist ethnic genocide committed by the Nazis. But respecting the will of an individual also had the effect that those determined to commit suicide must not be prevented from killing themselves if they are unable to have others assist them voluntarily. Thus, the right of individual euthanasia is based on the same principle as respect for autonomy which collective "euthanasia" denies" (Wolf, 2000, p. 224).

${ }^{6}$ These two terms are encountered directly by visiting the homepage of Dignitas Schweiz: http://www.dignitas.ch/ (Retrieved March 4, 2018).

${ }^{7}$ The German Federal Supreme Court $(B G H)$ talks about an "unlawful act" (BGHSt 6,147,153; 46, 279, 246). On the legal dimension and in reference to the philosophy of jurisprudence (Hillgruber, 2015, pp. 115-140; Rothhaar, 2015, pp. 101-114). 


\section{II.}

Let us find out whether a reference to concepts such as autonomy and dignity is in fact convincing. First of all, there is the question: To what extent are our demands in that respect actually the manifestation of a balanced consideration? What role do our worries, our illnesses and the resulting disabilities play? In what life situation does someone express the desire to live no longer? In a situation of suffering or in a marginal situation? What are the effective motives of someone who articulates the desire to die with "self-determination"? Not wanting to be a burden for others? Is there perhaps a hidden fear of pain and loneliness? The work of professional palliative physicians and hospice workers seems to clearly substantiate that when pain is taken away and attention is paid, the wish for a "self-determined" end disappears in most cases. ${ }^{8}$

We don't want to overlook that the desire for death on demand can soon lead to another "drive". In Flanders (in Belgium) in the year 2007, 32\% of euthanasia cases were without consent (Cf. Chambaere, Bilsen \& Cohen, 2010, pp. 895-901). A look at the official statistics of the Regional Control Commission for Assisted Suicide in the Netherlands shows that the number of killed dementia patients has quadrupled in the last five years. Evidently, we are faced with a new variety of medical paternalism instead of self-determination.

A study at the University of Zurich and the Zurich University for Applied Sciences was dedicated to people who were diagnosed with a severe illness. Their initial reaction to this discovery was grief, hopelessness, fear of the future and the worry they would have to give up their independence. According to the study, there would have been a possibility of therapeutic help for some patients, but they wished to end their life with self-determination. (Sterbehilfe für Lebensmüde, 2008). ${ }^{9}$ Around $30 \%$ of the people affected came to the conclusion to end their life with the help of a "suicide organization"; that makes us think.

People do not only suffer physically. In the past, it was a common fear to wake up again in the coffin after being buried alive. Today we sometimes worry about high-performance medicine that may prevent us from dying. Such worries and thoughts should be taken seriously in the context of high-tech medicine, which places man in his finality and vulnerability at the center. Needles and medication are very important for fighting physical suffering, but we cannot treat anxiety or existential crises that way. "We know today that in the overwhelming number of cases the suicide wish is not due to physical ailments but due to a situation where we feel abandoned. A study from the Netherlands shows that in only 10 out of 187 cases pain alone was the reason for wanting euthanasia. In less than half of all cases did pain play any role at all" (Spaemann, 2013, pp. $32 \mathrm{f}$.)

It is an understandable desire to design our life as we wish right up to old age but when that is no longer possible, when we can no longer walk with ease but require a helping hand, life is not yet at an end. We depend on others from the moment we are born. There seems to be much fear of being dependent in old age, of no longer holding the reins in our own hands. That fear should be

\footnotetext{
${ }^{8}$ However, it is not always easy - even in a hospice - to accompany a patient in the last stage of life and to pay him/her the proper amount of attention, as shown for example in the five TAZ discussions with people who are spending the end of their life in a hospice. There can be too much and too little attention paid by people who accompany patients. The woman in the first talk emphasized that it was important for her to have no pain and no help from others. She had told her children not to visit her to avoid seeing her. In the same breath, the 72-year-old repeated; "Take your time if you have children. Make time for your parents". The third patient emphasized that she did not want to be a burden to her children, and that she did not want too much attention. "The fact is that my children are suffering, and that bothers me. My three daughters are making it a little difficult for me because they [...] pay an excessive amount of attention to me" (Kurz vor dem tod, 2018).

9 A study in Basel was able to show great flaws in the Exit Organization: for more information, visit http://www.nzz.ch/aktuell/startseite/article7KHGS-1.464198
} 
taken seriously and should not be falsely interpreted as a call for freedom and autonomy. For example, freedom could manifest itself by turning away from the misbelief that we can do everything by ourselves and that in the final analysis we can get along in life without others (Cf. Maio, 2014, p. 179).

Obviously, the call for suicide assisted by a physician and for the "autonomy of the patient" depends on a certain view of life: Death is regarded as the work of man. Death is not expected, not understood as a given, but interpreted as something we can do, control and design ourselves (Cf. Maio, 2012, p. 360). This gradually changes our view of man who elevates himself to the "Lord and Master" over the living and the dead. It is precisely this wish to control everything right up to death that can very quickly turn us into our own slave. In that sense we can read what Johannes Rau, Germany's former Federal President, said: "What appears to strengthen our selfdetermination, can, in fact, let us fall victim to blackmail" (Rau, 2001, p. 24).

The two terms, autonomy and dignity already have a long tradition. The Greeks located the former in political philosophy and used it when they talked about man's morality. In many discussions, autonomy sounds virtually like a conjuring spell. When we listen carefully, it gives us not only the idea that we are removed from any moral obligation, but autonomy does not mean that we can do whatever we want; it doesn't mean freedom of arbitrariness. Also, to respect the autonomy of our opponents does not mean to meet all their demands. On the one hand, the term means that humans, regardless of empirical circumstances and motives, can shape their own lives. It also means that they can commit themselves to moral law. Suicide based on evaluating life situations ("balanced suicide") cannot be justified with autonomy in the sense of a moral selfobligation and bound to moral law.

Thus, a sick person's autonomy cannot mean that physicians or the nursing staff should try to do everything the patient imagines. (See also Pöltner, 2006, p. 266) Instead, the patient must also respect the autonomy of the nursing staff and the physicians, who are subject to moral law as well. Their work should always be for the benefit and for the sake of the patient which - last but not least - also distinguishes them from medicine men. In European medical ethics, this has been firmly rooted since antiquity: The Hippocratic Oath states: "I will give no one a product of lethal effect at their request, nor will I give any such advice" (Hippocrates, 2007, p. 54). The first sentence in the Grundsätze der Bundesärztekammer zur ärztlichen Sterbebegleitung [Principles of the Federal Medical Association on Physicians' Care for the Dying] gets to the point as follows: "It is the physician's duty to keep the patient alive while observing the patient's right of selfdetermination, to protect and restore health, to alleviate suffering and to assist the dying until death" (Grundsätze, 2011). Death cannot be a medical service. "The physician who kills a patient upon request enters, with his action, an orientation and disposition which in the last analysis must abolish his respect for the person" (Fuchs, 1997b, p. 86).

Good dying can include not wanting to exhaust all options of high-tech intensive medicine, to do without medical interventions or not to continue a therapy. ${ }^{10}$ That means allowing the dying process to continue. Death is not the goal but a good and humane way of saying farewell. "One omits everything that could prolong the dying process in a way that would be contrary to the dying patient's will and dignity; at the same time, one does everything to make this process tolerable" (Beckmann, 1998, p. 149) One agrees to the patient's dying, his death is not self-inflicted. ${ }^{11}$

\footnotetext{
${ }^{10}$ The Federal Supreme Court Bundesgerichtshof justified this with patient autonomy (BGHSt pp. 11,111, 113-115).

11 "The direct objective is [...] pain control which liberates the dying of constant unbearable pain; and as possible (not certain) side effect we must put up with the risk that the onset of death may be hastened, for example because the painkilling medication leads to respiratory depression. But we can only accept this evil of indirect killing as long as
} 
Today, pain can be very well controlled in palliative medical care. The concept of palliative care is being expanded. Ideally, it involves physicians, nursing teams, psychologists, clergymen, physiotherapists and volunteers hand-in-hand to accompany the seriously ill, to maintain their quality of life as well as possible and to allow good symptom control and pain therapy. Accompanying others in situations characterized by pain and illness is a challenge for the companions who must allow issues of finality and fragility to arise in their own life and who must find time for talks with the patient. ${ }^{12}$ Respecting the autonomy of patients means to recognize them as persons and not to place their existence at disposal. The purpose must be to take away the patients' fear and pain, not their life. ${ }^{13}$

Today, people live longer than ever. In financial terms, the last stage of life is expensive, especially when it is characterized by illness and the need for care. A study by the University of Cologne indicates that there are presently about 600,000 people in Germany older than 90, with the tendency rising. We can at least assume that discussions about assisted suicide have again ignited for financial reasons. In a novel with the significant title, Der moderne Tod. Vom Ende der Humanität [Modern death: The end of humanity], we find the following view about death and dying that makes us pay attention:

"When there are inadequate funds for saving everyone who could be saved by purely technological means and with modern treatment, we either have to leave it to chance who must die, or we must make a rational selection that depends on a comparative evaluation of human lives; there is no third option because there simply are not enough funds to save everyone" (Wijkmark, 2001, p. 31).

Now, about the dignity of man. The Universal Declaration of Human Rights begins with the statement that "all human beings [...] are born free and equal in dignity and rights". Of course, this Declaration must be seen against the background of the $20^{\text {th }}$ century's bestial reigns of terror, but the idea of human dignity is much older. In the schools of the Stoics, in the Christian Middle Ages, in the Italian Renaissance and in classical German philosophy, there was distinctive reflection about this ethical, politically practical and legal term.

Man is a creature of dignity not due to income, knowledge, social status, sex, religion or race. All human beings are entitled to dignity regardless of all the differences which exist and have always existed in mankind; human beings are equal in that they are born of humans and simply are humans. The deciding factors are not mental abilities or special characteristics such as being able to suffer or being social.

The term "dignity" means that humans have an "absolute value". In other words; Man is superior at all costs. Things around us have a value and can be replaced by other things which have the same price tag. There is nothing that would be an equivalent for dignity. Therefore, ideas as those in the novel cited above are impermissible. Dignity is not something awarded by others or that could be lost again - not even in the context of a serious illness. Human dignity is considered something

\footnotetext{
this side effect is not foreseeable with certainty. If we choose the doses of the medication so high that the patient's death is inevitable, we can no longer speak of an unwanted side effect (Schockenhoff, 2013, pp. 275 f).

${ }^{12}$ Pain and suffering are experienced as unpleasant. Quite often, our own body is experienced as foreign in this context. The concept of time changes as well. Questions of purpose enter our mind, and we do not always succeed in finding the answer (on the context of suffering see Bozzaro, 2015a, pp. 13-36; Bozzaro, 2015b, pp. 93-106).

${ }^{13}$ On Nov. 5, 2015, the German Bundestag passed a law concerning the upgrading of palliative possibilities and the better care of patients with a serious illness.
} 
given. If dignity were awarded for some special achievements, not all human beings would be carriers of human dignity. Some would be dignitaries and others not.

We cannot observe human dignity under the best of microscopes. It is related to our actions as persons and not to naked events. Dignity cannot be weighed. Human dignity does not mean life without worries and physical disabilities; it is rather life with enough chances for all, i.e. possibilities of communication, care and other social goods and characteristics. ${ }^{14}$ It means that life is inviolable. The term "dignity" means man's unavailability.

"We cannot attach the inviolable in man to one or more ensembles of characteristics. It only makes sense to talk about the "inviolable", i.e. about the dignity which everyone keeps, no matter what characteristics have been taken away or stolen from him. If dignity were not based on circumstances but - such as health - on characteristics, property or processes, we would lose it to the extent in which it is violated" (Schweidler, 2001, pp. $11 \mathrm{ff}$.)

As we read in Kant, probably the most important "master coiner" of this term, dignity means that humans must not be handled like objects. We must treat them with respect. Here is what the "Königsberg Philosopher" wrote: "Respect, which I have for others or which others can expect of me, is the recognition of dignity in other human beings, i.e. a value that has no price, no equivalent against which the object of evaluation may be exchanged" (Kant, 1914, p. 462).

We do not derive the sense of human life from being a function for something else or someone else; Man must be the end in itself. (Kant, 1911, p. 429) This purpose limits all instrumental access. According to Kant, dignity is rooted in autonomy. As persons, we are creatures of freedom and reason.

"Reasonable nature", Kant writes, "is different than all else because it determines a purpose of its own" (Kant, 1911, p. 437) Thus, we are characterized in that we can behave morally. Naturally, in the course of our life, the radius of our freedom changes. It may differ in our old age from that of a young man who is still facing his life. The opportunities connected with freedom also vary with social status. A head of government or the Pope have other opportunities than students or cleaning staff. These examples show that it is not a matter of actually acting in freedom but that humans can be free. Dignity "includes not only the freedom to choose one's way of life selfreliantly. As members of the human family, we all have duties to ourselves as well as to others. In a self-determined life, there is freedom only in living together with others, and our freedom is therefore always limited by the freedom of the others. Therefore, the idea of dignity includes the duty to respect each other" (Kather, 2007, p. 8).

For Kant, "self-disembodiment", as he calls suicide, is not an expression of man's freedom. In his Metaphysics of Morals, we can read as follows:

"To destroy the subject of morality in our own person is as much as removing the existence of morality itself from the world, although morality is an end in itself. Therefore to dispose of oneself as a mere means to an end means to degrade mankind in our person (Homo noumenon) to which man (Homo phaenomenon) had been entrusted for preservation" (Kant, 1914, p. 423).

\footnotetext{
${ }^{14}$ Human dignity is not a synonym for "life quality till the end". It does not grant a guarantee for a happy life: "The pragmatic reason for living is happiness. Does that mean I can take my life when I can't live in happiness? No! It is not necessary for me to live in happiness for as long as I live. But it is necessary that I live honourable for as long as I live" (Kant, 1990, p. 165).
} 
According to Kant, the subject of freedom and autonomy is wiped out by precisely that act. In a deeper sense, it is a self-contradiction of human freedom (Cf. Kant, 1908, pp. 422 f.; Kant, 1911, pp. 421 f., 429; Kant, 1913, pp. 75 f.; Kant, 1990, pp. 161-167). Such an act contradicts the supreme duty to ourselves and cancels the condition of all duties. As far as reason is concerned, there can be no purpose in giving oneself up. That would undermine all ethics. The existence of reason must not be jeopardized or stamped out. As long as my maxims, by which my will is determined, could always become a universal law, self-disembodiment is contrary to that imperative.

According to Kant, the road to self-disembodiment is not an expression of autonomy, but exactly the opposite: heteronomy. There are many factors which influence a person in such an extreme life situation to think it would be better not to exist than to live and we can supplement Kant: A decision to commit suicide does not only affect this one person: Left behind are people at a loss who often have to suffer unbearably after such a step. People connected to persons willing to commit suicide have the obligation not to agree with them that their life makes no sense anymore and that being without them would be better for everyone. Instead they should be helped to rediscover their autonomy and to gain a new perspective by applying reason and by accepting support from fellow human beings.

In the footsteps of Kant, the answer to the question what it means to die in dignity should be; Dying in dignity is dying in the awareness that life is not a disposable commodity. Just as our own life is indispensable, so is the life of our fellow human beings.

\section{References}

AUGUSTINE (2007): Vom Gottesstaat (De civitate Dei). München: dtv.

BECKMANN, J. P. (1998): Patientenverfügungen: Autonomie und Selbstbestimmung vor dem Hintergrund eines im Wandel begriffenen Arzt-Patienten-Verhältnisses. In: Zeitschrift für medizinische Ethik, 44, pp. 143-156.

BORASIO, G. D. (2014): Selbstbestimmt sterben. Was es bedeutet. Was uns daran hindert. Wie wir es erreichen können. Munich: dtv.

BOZZARO, C. (2015a): Schmerz und Leiden als anthropologische Grundkonstanten und als normative Konzepte in der Medizin. In: G. Maio, C. Bozzaro \& T. Eichinger (eds.): Leid und Schmerz. Konzeptionelle Annäherungen und medizinethische Implikationen. Freiburg \& Munich: Alber, pp. 13-36.

BOZZARO, C. (2015b): Der Leidensbegriff im medizinischen Kontext: Ein Problemaufriss am Beispiel der tiefen palliativen Sedierung am Lebensende. In: Ethik in der Medizin, 27, pp. 93-106. BRIEF VON JOHANNES PAUL II AN DIE ALTEN MENSCHEN (1999): [online] [Retrieved March 4, 2018] Available at: https://w2.vatican.va/content/john-paul-ii/de/letters/1999/docu ments/hf_jp-ii_let_01101999_elderly.html.

BROSCHE, W. (2014): Das Leben ist der Güter höchstes nicht. [online] [Retrieved March 4, 2018 ] Available at: http://www.theeuropean.de/wolfgang-brosche/9152-sterbehilfe-debatte-lustvollkatholisch-verrecken.

CHAMBAERE, K., BILSEN, J., COHEN, J. et al. (2010): Physician-assisted deaths under the euthanasia law in Belgium: a population-based survey. In: Canadian Medical Association Journal, 182(9), pp. 895-901.

CHARLESWORTH, M. (1997): Leben und sterben lassen. Bioethik in der liberalen Gesellschaft. Hamburg: Rotbuch Verlag.

DWORKIN, R., NAGEL, T., NOZICK, R., RAWLS, J., SCANLON, T. \& THOMSON, J. J. (1997): Philosopher's Letter. [online] [Retrieved March 4, 2019] Available at: http://www.nybooks.com/articles/1997/03/27/assisted-suicide-the-philosophers-brief/ 
FUCHS, T. (1997a): Was heißt ,töten‘? In: Ethik in der Medizin, 9, pp. 78-90.

FUCHS, T. (1997b): Euthanasie und Suizidbeihilfe. Das Beispiel der Niederlande und die Ethik des Sterbens. In: R. Spaeman \& T. Fuchs (eds.): Töten oder sterben lassen? Freiburg: Herder, pp. 31-107.

GRUNDSÄTZE DER BUNDESÄRZTEKAMMER ZUR ÄRZTLICHEN STERBEBEGLEITUNG (2011): In: Deutsches Ärzteblatt, 108(7), pp. 346-348. [online] [Retrieved September 22, 2019] Available at: http://www.bundesaerztekammer. de/fileadmin/user_upload/downloads/Sterbebegleitung_17022011.pdf

HATTLER, J. \& KOECKE, J. C. (2020): Biopolitische Neubestimmung des Menschen. Menschenwürde und personale Autonomie. Wiesbaden: Springer VS.

HILLGRUBER, C. (2015): Die Bedeutung der staatlichen Schutzpflicht für das menschliche Leben und der Garantie der Menschenwürde für eine gesetzliche Regelung zur Suizidbeihilfe. In: S. T. Hoffmann \& M. Knaup (eds.): Was heißt: In Würde sterben? Wider die Normalisierung des Tötens. Wiesbaden: Springer VS, pp. 115-140.

HIPPOCRATES: Der Eid (2007): In: J. Kollesch \& D. Nickel (eds.): Antike Heilkunst. Ausgewählte Texte aus den medizinischen Schriften der Griechen und Römer. Stuttgart: Reclam, pp. 53-55.

HOERSTER, N. (1998): Sterbehilfe im säkularen Staat. Frankfurt a. M.: Suhrkamp.

HOERSTER, N. (2018): Zur Legitimität der Sterbehilfe, In: Information Philosophie, [online] [Retrieved September 22, 2019] Available at: http://www.information-philosophie.de/?a=1\&t= $2538 \& \mathrm{n}=2 \& \mathrm{y}=1 \& \mathrm{c}=1$

HOFFMANN, T. S. (2009): Töten auf Verlangen - eine Wohltat?. In: G. Kaster (ed.): Sterben an der oder durch die Hand des Menschen, Münster: Dialog-Verlag, pp. 60-77.

HOFFMANN, T. S. (2015): Lasst die Finger davon. In: FAZ, Nov. 4, p. 9.

HOFFMANN, T. S. \& KNAUP, M. (2015): Was heißt: In Würde sterben? Wider die Normalisierung des Tötens. Wiesbaden: Springer VS.

JOHN PAUL II ACADEMY FOR HUMAN LIFE AND THE FAMILY COMMENTS ON THE MEETING OF THE WORLD MEDICAL ASSOCIATION, EUROPEAN REGION, ON ENDOF-LIFE QUESTIONS, HOSTED BY THE PONTIFICAL ACADEMY FOR LIFE (2017): [online] [Retrieved March 4, 2018] Available at: https://www.corrispondenzaromana.it/wpcontent/uploads/2018/02/JAHLF-on-PAV-declaration.pdf

KANT, I. (1908): Metaphysische Anfangsgründe der Tugendlehre, Akademieausgabe, vol. VI, ed. Königlich Preußische Akademie der Wissenschaften. Berlin: Reimer.

KANT, I. (1911): Grundlegung zur Metaphysik der Sitten, Akademieausgabe, vol. IV, ed. Königlich Preußische Akademie der Wissenschaften. Berlin: Reimer.

KANT, I. (1913): Kritik der praktischen Vernunft, Akademieausgabe, vol. XIX, ed. Königlich Preußische Akademie der Wissenschaften. Berlin: Reimer.

KANT, I. (1914): Die Metaphysik der Sitten, Akademieausgabe, vol. VI, ed. Königlich Preußische Akademie der Wissenschaften. Berlin: Reimer.

KANT, I. (1990): Eine Vorlesung über Ethik. Frankfurt a. M.: Fischer.

KATHER, R. (2007): Person. Die Begründung menschlicher Identität. Darmstadt: WBG.

KNAUP, M. (2016): Der neue $§ 217$ (StGB). In: Imago Hominis, 23(1), pp. 9-12.

KÜNG, H. (2014): Glücklich sterben? Mit dem Gespräch mit Anne Will. Munich \& Zurich: Piper. KURZ VOR DEM TOD (2018). [online] [Retrieved September 22, 2019] Available at: http://www.taz.de/!5487927/

MAIO, G. (2012): Mittelpunkt Mensch: Ethik in der Medizin. Ein Lehrbuch. Mit einem Geleitwort von Wilhelm Vossenkuhl. Stuttgart: Schattauer. 
MAIO, G. (2014): Medizin ohne Maß? Vom Diktat des Machbaren zu einer Ethik der Besonnenheit. Stuttgart: Trias.

PÖLTNER, G. (2006): Grundkurs Medizin-Ethik. Vienna: Facultas.

RAU, J. (2001): Wird alles gut? - Für einen Fortschritt nach menschlichem Maß. In: S. Graumann (ed.): Die Genkontroverse. Grundpositionen. Freiburg, Basel \& Vienna: Herder, pp. 14-29.

ROTHHAAR, M. (2015): Autonomie und Menschenwürde am Lebensende. Zur Klärung eines umstrittenen Begriffsfelds. In: S. T. Hoffmann \& M. Knaup (eds.): Was heißt: In Würde sterben? Wider die Normalisierung des Tötens. Wiesbaden: Springer VS, pp. 101-114.

SANDEL, M. (2015): Moral und Politik. Berlin: Ullstein.

SCHOCKENHOFF, E. (2013): Ethik des Lebens. Grundlagen und neue Herausforderungen. Freiburg: Herder.

SCHWEIDLER, W. (2001): Das Unantastbare. Beiträge zur Philosophie der Menschenrechte. Münster: LIT.

SPAEMANN, R. (2002): Grenzen. Zur ethischen Dimension des Handelns. Stuttgart: Klett-Cotta. SPAEMANN, R. (2013): Die Vernünftigkeit eines Tabus. In: R. Spaemann \& B. Wannenwetsch (eds.): Guter schneller Tod? Von der Kunst, menschenwürdig zu sterben. Basel: Brunnen, pp. 940.

STERBEHILFE-STREIT IN BELGIEN (2017): [online] [Retrieved March 4, 2018] Available at: http://www.archivioradiovaticana.va/storico/2017/10/02/sterbehilfe-streit_in_belgien_vatikan_gi bt_orden_letzte_cha/de-1340310

STERBEHILFE FÜR LEBENSMÜDE (2008): [online] [Retrieved March 4, 2018] Available at: http://www.nzz.ch/aktuell/startseite/sterbehilfe-lebensmuede--1.1215812

STRIET, M. (2015): Gottes Schweigen. Auferweckungssehnsucht - und Skepsis. Ostfildern: Grünewald.

THOMAS AQUINAS: Summa Theologiae II-II.

TODKRANKE AMERIKANERIN BRITTANY MAYNARD NIMMT SICH DAS LEBEN (2014): [online] [Retrieved March 4, 2018] Available at: https://www.welt. de/newsticker/dpa_nt/infoline_nt/brennpunkte_nt/article133924977/Todkranke-AmerikanerinBrittany-Maynard-nimmt-sich-das-Leben.html

WIJKMARK, C.-H. (2001): Der moderne Tod. Berlin: Gemini Verlag.

WOLF, J. C. (2000): Sterben, Tod und Tötung. In: U. Wiesing (ed.): Ethik in der Medizin. Ein Reader. Stuttgart: Reclam, pp. 200-225. 